\title{
Is there something new and interesting in my article?
}

\author{
Makalemde yeni ve ilginç bir şey var mı? \\ O. Şahap Atik, MD \\ Professor of Orthopedic Surgery, Turkish Joint Diseases Foundation, Ankara, Turkey
}

We prefer to publish original research and valuable data like all academic journals.

Uncontrolled studies may show beneficial effects for several conditions. Whereas results of controlled trials are not as definitive. Therefore, orthopedic surgeons should be aware that there is still uncertainty about the evidence behind these issues. ${ }^{[1]}$ Everything new may not be good enough. ${ }^{[2]}$

Orthopedic surgeons all over the world are performing excellent surgeries. However, overuse and abuse of surgeries in almost every country are getting more common day by day.

We must keep in mind that we are physicians first. Many times, surgery is unnecessary and nonsurgical procedures may be beneficial, too.

Original research question or hypotheses, and appropriate study design are crucial for obtaining valid and scientific results. The methods should explain the steps taken to produce the results. It should contain adequate details for other researchers to replicate the study.

We also prefer to publish articles with long follow-up with new data, or even articles with short follow-up but with new data.

Finally, we believe that well-written case reports can play a relevant role in medical education. However, they must be original like any scientific article and give a new and valuable message. ${ }^{[3]}$

\section{REFERENCES}

1. Atik OŞ. How much effective are supplements in the treatment of osteoarthritis? Eklem Hastalik Cerrahisi 2018;29:129.

2. Atik OŞ. Platelet-rich plasma: Everything new may not be good enough! Eklem Hastalik Cerrahisi 2017;28:63.

3. Bağatur AE, Yalçınkaya M. How to write a case report? or... not write at all? Eklem Hastalik Cerrahisi 2014;25:165-7. 